\title{
Family Governance Mechanisms in Moroccan Family Businesses: An Exploratory Study
}

\author{
Hiba Birgach ${ }^{1}$, Taib Berrada El Azizi ${ }^{2} \&$ Badr Habba ${ }^{1,2}$ \\ ${ }^{1}$ Larego Encg School, Cadi-Ayyad University, Marrakech, Morocco \\ ${ }^{2}$ Chair of Moroccan Family businesses ESCA Ecole de Management, Casablanca, Morocco \\ Correspondence: Hiba Birgach, Encg School, Cadi-Ayyad University, Boulevard Allal Al Fassi, Marrakech \\ 40000, Morocco. E-mail: hiba.birgach@gmail.com
}

Received: March 5, 2020

doi:10.5539/ijbm.v15n8p101
Accepted: April 28, 2020

Online Published: July 10, 2020

\begin{abstract}
Purpose - Despite the importance attached to the governance of family businesses, few studies have focused on the importance of family business governance in the Moroccan context. This article provides some specificities of family firms and an overview of main governance mechanisms identified in the literature while presenting the main contributions of agency and stewardship theories. We introduce a governance approach centered on the issue of strengthening family ties and increasing the commitment of family members to the firm. The purpose of this paper is to identify the governance mechanisms adopted by CEOs of Moroccan family businesses of the second generation.

Method - the authors used a qualitative method, using face to face semi-structured interviews among ten CEOs of family businesses in Morocco. Through the analysis of verbatim responses of Moroccan CEOs, we were able to identify some of the governance mechanisms they adopt to ensure a certain continuity of their business.

Findings-The results suggest that most of the Moroccan managers opt for an informal and unwritten system of governance. According to them, the important thing is to share values and vision while maintaining communication. Even family meetings remain informal, the crucial thing is to preserve family solidarity, as far as the system of governance is known by all the members. We have identified three informal governance mechanisms, family meetings, task management, and sharing a family vision. The results have also shown some of the sources of conflicts among family members.

Practical implications - This paper helps to raise awareness among Moroccan leaders on the importance of governance. Whether formal or informal, it is essential to have common rules shared by family members, which will enable the firm to last over time.

Originality - This paper contributes to research on family businesses by exploring a different context especially in terms of culture and country values. Our paper has the originality to focus on a specific area of investigation, namely the Moroccan context, where the management model of family businesses is different from anterior contributions.
\end{abstract}

Keywords: Qualitative research, Family business, family governance mechanisms, Stewardship theory, Agency theory

\section{Introduction}

Over the past decade, several research studies have recorded the importance of family businesses, mainly known for their specific characteristics within the scientific community (Suess, 2014; Chrisman, 2017; Lee,2019). Being aware of the particularities of this type of firm, researchers studied family business issues in a range of different fields and disciplines. Furthermore, according to statistics revealed by the International Family Enterprise Research Academy, the predominance of family businesses in the world, especially in the European countries (IFERA, 2015). The definitions of family firms vary widely among researchers (Chua \& al., 1999) but some criteria allow us to make a difference between family and non-family firms (Astrachan \& Shanker, 2003; Chua et al., 1999). Chua et al. (1999) defined family firms as «organizations that are governed and/or managed to shape and pursue the vision of the business held by a dominant coalition controlled by members of the same family or a small number of families in a manner that is potentially sustainable across generations of the family or families». 
Indeed, the focus on family businesses is justified by some unique characteristics that make them different from managerial businesses. In addition to that, not all family businesses are homogeneous. They can differ from one country to another. The cultural context has then a strong impact on the family firm functioning. Therefore, researchers took into consideration the values, of different cultures while studying family businesses (Sharma and Chua, 2013).

Besides, studies about family businesses highlighted the importance of family governance, and help understand the strategic dimension to set up an effective system of governance (Chrisman, Chua, Pearson, \& Barnett, 2012; Chrisman \& Holt, 2016). Researchers have attached the topic of family governance to several issues such as succession (Handler, 1994), Goals and resources (Chrisman, Sharma, Steier, \& Chua, 2013), Performance (Kellermanns et al, 2019) or Conflicts between family members (Friedman, 1991; Großmann et al., 2015; Caputo et al., 2018). At this level, studies confirm the idea of family governance mechanisms as a challenge and enhance their importance as a factor in stabilizing and preserving family harmony, which is at the heart of sustainability (Berent-Braun \& Uhlaner, 2012; Fahed-Sreih, 2009; Tower et al., 2007).

Governance is defined as the establishment of a set of mechanisms made internally by the firm to structure and regulate the actions of family members. The main purpose is to ensure family control and strike balance between family and business (Gallo and Kenyon-Rouvinez, 2005). Furthermore, family governance mechanisms can order relationships between family members (Berent- Braun \&Uhlaner, 2012; Suare \& Santana-Martin, 2004), and strengthen emotional wealth (Gomez-Mejia et al., 2011).

In Morocco, the awareness about the importance of these assets and the prevalence of the economic weight of family businesses allowed a clear improvement of their image. Yet, despite their organizational resilience and their performance, a large proportion of family businesses struggle to survive beyond the first generation. We considered it relevant to focus on the main causes of this economic and social break (Habba \& Berrada, 2018). Indeed, the family business is characterized by a double dimension including business and family. This cohesion between business and family is usually complex because family members do not necessarily agree on the decisions, leadership, or long-term strategy, which can inevitably create conflicts between them.

Otherwise, there's no «one size fits all» about family governance mechanisms. Each Family firm creates its unique governance structure because it generally depends on the family values in a particular and cultural context (Jaffe \& Lane, 2004). The main purpose of this article is to present an exploratory study on the governance mechanisms adopted by Moroccan family businesses. Indeed, the problems threatening the continuity of the company, such as management problems or conflicts between family members, have drawn our attention establishing the mechanisms of governance at the heart of the main interest of this article. We conducted semi-structured interviews with CEOs of 10 Moroccan family businesses. However, we find it relevant to combine both contributions of agency and stewardship theories instead of replacing one with the other (Madison \& al., 2016).

The remainder of this article is divided as follows: In Section 1, we introduce the conceptual and theoretical frameworks about family governance. In section 2, we justify methodological choices. In Section 3, we expose the main finding of the exploratory study. Finally, section 4 provides a broader discussion and some directions for future research.

\section{Literature Review}

\subsection{The Relevance of Corporate Governance in Family Businesses}

The definitions of the family business differ within studies. However, what generally emerges from the academic work is that a family firm refers to a business in which the family holds the majority of voting control and it is driven above all by the desire to transfer the business to other generations. This statement makes the succession of the business the main goal of the family. Most of the literature on the subject attests that, beyond the cultural divisions between countries and economies, family management, in the broadest sense of the term, is largely dominated by the logic of preserving and securing the company as a family asset (Siebels et al., 2012). Beyond establishing a management framework specific to family businesses in terms of both objectives and policies adopted, this specificity is changing our traditional reflection on corporate governance in the case of family businesses. Family firms are largely different from non-family ones. The first main particularity of a family business is the long-term survival goal. In other words, the main purpose of family owners is to make the family business last over time. This mindset can affect their decisions in the long term. The second particularity is that the family has not only economic goals (financial value), but also non-economic goals (Emotional value), (Allioui \& Habba, 2019). This means that family members can accept low levels of financial value if the emotional value is high (Hirigoyen, 2009; 2014). Finally, family members cannot quit easily the business, it is a 
matter about protecting the interest of the family (Ward, 1997; Botero et al., 2016).

However, the involvement of the family in the business can play a major role in the success of the family business or on the contrary can be responsible for its destruction (Eddleston \& Kellermanns, 2007). The higher the level of generations, the commitment and family harmony decrease over time (Ward, 1997, Romano et al., 2000). Consequently, this situation leads to different types of conflicts between family members (Whiteside and Brown, 1991). Going even further, family conflicts can constitute a threat to the continuity and sustainability of the family business. Indeed, it is not only a matter of setting up a system of governance regulating the company, but it is also a question of setting up a system regulating the actions of the family (Olson et al., 2003). Therefore, researchers have devoted considerable effort to family and business governance (eg., Chrisman et al., 2019; Lee, 2019).

This analysis leads us to identify the main risks that justify the need to establish a family governance system.

\section{- $\quad$ The risk of conflicts between family members}

The main contribution that emerges from the academic work defines the family business as a symbiosis between various subsystems (family, business, family members). While this vision allows for an integrated vision, it also reminds us of the occurrence of organizational and human concerns arising in these companies as a result of the cohabitation between social systems whose aims are a priori incompatible (Pieper \& Astrachan, 2008). Such a situation would lead, among other things, to the confusion of roles, conflicts of interest, and rivalries among family members or clans (Kellermanns et al., 2018). However, conflicts reduce satisfaction and family solidarity (Jehn, 1995) and impact the firm's performance (McKee, Madden, Kellermanns, \& Eddleston, 2014).

\section{- $\quad$ The risks of making inappropriate strategic decisions}

The combination of ownership of the firm's capital and management within family structures leads in various situations to limited effectiveness. This underperformance of some family businesses is mainly due to nepotism bias and the lack of competition for the most qualified person to lead the family business (Allouche \& Amann, 1998). This can also concern the choice of investment policy. Generally, we find an absence of significant debt because managers don't search for a high level of performance, which may weaken the firm in the long term. On the contrary, the question of over-investment in family businesses arises. Indeed, the ambiguity surrounding the investment decision of this category of firms sometimes contributes to a worsening of their difficulties. There is such a lack of rigor driven by a common idea. While information asymmetry is relatively low between family shareholders, the managers of family firms do not need to have an investment strategy based on clear criteria.

\section{- Managers and aversion for planning the succession}

The question of planning the succession in a family business is a taboo topic. Family members find it difficult to talk about succession because of the fear of failure but also cultural values. In addition to these attitudinal factors, there is also the nature of the transferable assets. The main resources of a family business are, for the most part, composed of specific assets "because of the interaction that occurs there between the family, the individuals-actors and the business" (Habbershon et al., 1999). From this point of view, the main identified resources include the commitment of family members (Neubauer et al., 1998), family culture, and reputation (Dyer, 1986).

\subsection{Family Governance Mechanisms}

Governance plays an important role in resource deployment and conflict mitigation among family members (Daily \& al., 2003, p. 371). It's about settling to an equilibrium between the family's interest and the business (Sirmon \& Hitt, 2003; Steier et al., 2015). To realize this, the family members need to set governance mechanisms effectively.

As noted above, there is an ongoing debate in the academic literature about the main governance mechanisms used by family businesses in the world (Suess, 2014; Botero et al, 2016; Chrisman, 2017). FGM (Note 1) vary from informal mechanisms to formal ones. The most common formal FGM mentioned in the literature are family meetings (Habbershon \& Astrachan, 1997; Neubauer \& Lank, 1998), the family council (Neubauer \& Lank, 1998), and family constitution (Suare \& Santana-Martin, 2004; Arteaga et al., 2017).

- Family meetings: While in most cases, during the founder's stage of the business, the family meeting can be informal or formal, it's a discussion meeting that brings together all the family members to discuss issues and problems related to both business and family (Habbershon \& Astrachan, 1997; Neubauer \& Lank, 1998). This meeting allows all family members to keep abreast of the company's issues and concerns. It also allows them to express their opinions on firm development and family matters. Family meetings also help to avoid potential 
conflicts that may arise among family members due to unequal access to information and other resources.

- Family Council: This is the case when the family business is at the founder's stage and the founder brings together his or her limited number of children in a periodic family committee to communicate about the issues on the agenda, to build a concerted vision but also often to limit potential or current conflicts. Another situation arises when the family has reached a considerable size, usually more than 30 members, it becomes almost impossible for the family assembly to complete discussions and allow rapid, consensual, and effective decision-making. At this point, it becomes essential to set up this second mechanism, the family board (Gersick et al., 1997), which is then formed, as a representative governance structure for the family assembly in coordinating the interests of family members about their business. In the second case, the board allows a better consensual vision within the family but puts more sharply the question of the legitimacy of its members.

- Family constitution: The family constitution has no legal value, but a moral connotation that is even stronger. Signed by all members, we can find all the family's values and sometimes we can find procedures for recruiting family members; it outlines the family's commitment to the firm's central vision and mission. It also defines the roles, compositions, and powers of the firm's main governance system: family members/shareholders, board of directors, and managers. The family constitution clarifies the relations between governance structures and specifies how family members can contribute to the governance of their family business.

However, if formal FGM can play an important role in regulating the business and family's actions, several studies have shown the importance of informal FGM in family firms (Astrachan, 2010). Those mechanisms are based on sharing family values and vision (Mustakallio \& al., 2002; Eddleston et al., 2010), enhancing family harmony (Pekdemir et al, 2013) and/or preserving socio-emotional wealth (SEW)through generations (Gomez-Mejia and al,2011). Informal governance mechanisms lead family members to respect some unwritten rules, help to discipline them and allow them to prioritize the collective interest (Combs, Penney, Crook, \& Short, 2010; Fama \& Jensen, 1983; Pollak, 1985).

\section{- Informal FGM and Shared values}

Values in family businesses have gained attention in a considerable number of studies (eg., Tapies \& al,2012; Dawson \& al,2019). In the academic sphere of family businesses, unanimity is not reached about the definition of value. According to Koiranen (2002), he refers value to 'desirable, importance, usefulness, or monetary worth'. In other words, values are a set of attitudes, principles, or ethical behaviors that can vary from one person to another. Furthermore, ward and al (1997) defined values as 'the cornerstone of human achievement and commitment. Values inspire people to do difficult things, to make commitments that require discipline, to stick to plans for the long haul'. In the context of the family business, Given that family and business goals are mostly heterogeneous, it is necessary to find a middle ground for a sustainable value system for the sake of the two subsystems (Hall \& al., 2001). Indeed, scholars are giving particular attention to values as a family governance mechanism (Parada \& al., 2010).

\section{- Informal FGM and socio-emotional wealth}

Gómez-Mejía, Tákacs Haynes, Nuňez-Nickel, Jacobson, and Moyano-Fuentes (2007) define socio-emotional wealth as 'the non-financial aspects of the business that meet the emotional needs of the family, such as identity, the ability to exercise family influence and perpetuate the family dynasty'. Besides, this concept shows that family businesses act differently from non-family businesses. The most striking point of difference is that they fear emotional loss more than financial loss. Well, the preservation of family commitment depends on the attention given to succession. Consequently, the intergenerational transfer of socio-emotional wealth depends on succession planning and the skills of the family business founders. Studies show also that socio-emotional wealth can negatively influence the performance of the family business after succession (Minichilli, Nordqvist, Corbetta, \& Amore, 2014).

\subsection{The Coexistence of Agency and Stewardship Theories in the Context of Family Businesses}

Scholars (eg., Madison \& al, 2017; Chrisman,2019) are giving more attention to the intertwinement of agency and stewardship theories (see Jensen \& Meckling, 1976; Davis, Schoorman, \& Donaldson, 1997) to study their contributions and influences on family firms. Thus, Madison (2016), argues that instead of studying each theory and its contributions, it is better to develop a combination of the two theories to have an effective governance structure. Studies about stewardship theory suggest that family ties promote the alignment of interests in cases where the family participates in ownership and management (Davis, Allen, \& Hayes, 2010; Pearson \& Marler, 2010; Vallejo, 2009). However, Agency theory confirms that family members can act for their own interest instead of acting for the group interest (Schulze, Lubatkin, \& Dino, 2003; Schulze, Lubatkin, Dino, \& Buchholtz, 2001). Such behaviors can be moderated by family governance mechanisms (Anderson \&Reeb, 2003; Chrisman, 
Chua, Kellermanns, \& Chang, 2007).

Apart from the effects of agency and stewardship theories on individual behavior, both theories have a positive effect on family business performance (Davis et al., 1997). The impact of the coexistence of the two theories on family business was studied by Madison \& al (2017). They identified four configurations that depend on the level of interaction between agency and stewardship theories. In a first configuration, when levels of agency governance and stewardship governance are high, it has a positive impact on the firm's performance. Consequently, setting up an agency and stewardship system of governance by controlling and monitoring agent behaviors at the same time. This situation will lead to increase performance and promote stewardship behaviors. On the other hand, with a low level of agency governance and a high level of stewardship governance, agents are stewards in the ideal conditions to succeed. But this implementation of control mechanisms in stewardship governance increases the risk of moral hazard to the extent that agents take advantage of its informal nature, and can exploit information and be opportunistic (Munyon \& al.,2016). This is the reason why agents are less opportunistic in the fourth configuration than in the third. This also explains the non-opportunistic nature of the agents in the second configuration. In fact, the governance of agency theory consists in implementing a set of mechanisms dealing with the asymmetry of information between the principal and the agent on the one hand and reduces the opportunistic nature of the agent that leads him to act in the interest of the principal, on the other hand.

\section{Methods}

A qualitative exploratory approach was chosen to study the family governance mechanisms applied by Moroccan family businesses. We need to understand more how managers of Moroccan family firms behave and how they manage their different issues. A detailed analysis was necessary to explore the context and experiences. We chose this method because Morocco is a country characterized by many cultural factors especially in the context of family businesses. In this regard, these factors should be explored and contextualized because literature highlighted some variables that are not necessarily applied in all contexts. Broadly, family businesses need to set up a governance structure when the company starts to grow through generations. That is the reason why we chose to focus on second-generation family businesses, a level in which family members face some difficulties and need to ensure the succession over time.

The survey is the most widely adopted method in management sciences. The particularity of the survey is that data can be collected using several themes. That is, the exploratory qualitative approach was conducted through semi-structured interviews by face to face conversation and Focus Group of CEOs of Moroccan family businesses of the second generation. We have targeted and contacted around fifty family businesses that are in the process of setting up a system of governance. Among the fifty companies, ten have agreed to be interviewed. This method is the most appropriate for data collection because, from a practical point of view, it is less time-consuming and less invasive, which facilitates access to firms.

We chose the most common data analysis method used in the management sciences which is content analysis. A good number of researchers try to define it. Bardin (2013) defines this method as "a set of techniques for analyzing the communications through systematic and objective procedures and for describing the content of messages, to obtain indicators (quantitative or not) allowing the inference of knowledge related to the conditions of production/reception (inferred variables) of these messages". Globally, content analysis is suitable for studies that use free or semi-structured interviews (Thietart, 2014). Particularly, we relied on narratives, as they represent a form of interpretive approach through which we can capture the main mechanisms governance applied by Moroccan family businesses.

The main goal of the researcher is to collect a set of information through a face-to-face conversation that leads to verbal communication. Thus, the collected data from interviews allows the researcher not only to have an idea about the respondent's thoughts but also to know the reality of the subject (Albarello L. \& al, 1995). In this study, we conducted interviews with ten CEOs of Moroccan family businesses from September 2018 to April 2019. Interviews lasted about one hour to one hour and thirty minutes. An overview of the interviewee's profile is presented (see Table 1). Table 2 describes the main characteristics of selected family businesses. 
Table 1. The main characteristics of the interviewees

\begin{tabular}{|c|c|c|c|}
\hline CEOs & Age & Academic and professional experiences & Sibling Rank \\
\hline CEO1 & Sixty & Studied management, joined the company just after graduation & The oldest sibling \\
\hline $\mathrm{CEO} 2$ & Thirty & Studied financial management, joined the company just after graduation. & $\begin{array}{l}\text { The youngest } \\
\text { sibling }\end{array}$ \\
\hline CEO3 & Fifty & The CEO is a successor after his father's death & The oldest sibling \\
\hline CEO4 & Thirty & Engineering studies, experience within the company & $\begin{array}{l}\text { The youngest } \\
\text { sibling }\end{array}$ \\
\hline CEO5 & Seventy & Accompanied his father from the company's launch and takes it over after his death. & The oldest sibling \\
\hline CEO6 & Thirty & Management studies & The oldest sibling \\
\hline CEO7 & Thirty & $\begin{array}{l}\text { Studied management, started the business with his brother after leaving his father's } \\
\text { company. }\end{array}$ & The oldest sibling \\
\hline CEO8 & Twenty & Studied management, joined the company after some professional experiences & The oldest sibling \\
\hline CEO9 & Thirty & Studied management, joined the company after graduation. & The oldest sibling \\
\hline CEO10 & Twenty & Studied management, had joined the company after graduation. & $\begin{array}{l}\text { The youngest } \\
\text { sibling }\end{array}$ \\
\hline
\end{tabular}

Table 2. The main characteristics of the companies

\begin{tabular}{|c|c|c|c|c|}
\hline Companies & Age & Activity area & Generation level & Relevant stakeholders \\
\hline 1 & $\begin{array}{l}51 \\
\text { years } \\
\text { since } \\
1968\end{array}$ & $\begin{array}{l}\text { Hotels, golf and } \\
\text { leisure }\end{array}$ & Second generation & $\begin{array}{l}\text { The company is owned and managed by } \\
\text { two families. The interviewee belongs to } \\
\text { the } 2 \text { nd generation. }\end{array}$ \\
\hline 2 & $\begin{array}{l}40 \\
\text { years } \\
\text { since } \\
1979 \\
\end{array}$ & $\begin{array}{l}\text { Packaging of } \\
\text { medicinal plants } \\
\text { and teas in cotton } \\
\text { bags }\end{array}$ & Second generation & $\begin{array}{l}5 \text { brothers manage the firm, the oldest } \\
\text { sibling is the CEO, the founder is no } \\
\text { longer in office but remains an adviser. }\end{array}$ \\
\hline 3 & $\begin{array}{l}43 \\
\text { years } \\
\text { since } \\
1976\end{array}$ & $\begin{array}{l}\text { Transport and } \\
\text { urban planning }\end{array}$ & Second generation & $\begin{array}{l}\text { the founder is dead, the stakeholders are } \\
\text { five people, } 2 \text { brothers, } 2 \text { sisters and a } \\
\text { cousin, the oldest son is the president } \\
\text { and the stakeholders are not fully } \\
\text { involved in the management }\end{array}$ \\
\hline 4 & $\begin{array}{l}45 \\
\text { years } \\
\text { since } \\
1976\end{array}$ & $\begin{array}{l}\text { Transport and } \\
\text { urban planning }\end{array}$ & Second generation & $\begin{array}{l}\text { The founder has } 5 \text { sons, } 2 \text { collaborate } \\
\text { with him in management, one son } \\
\text { assumes all the technical aspects and the } \\
\text { two other ones have not yet joined the } \\
\text { firm. }\end{array}$ \\
\hline 5 & $\begin{array}{l}51 \\
\text { years } \\
\text { since } \\
1968\end{array}$ & $\begin{array}{l}\text { Finishing and } \\
\text { painting }\end{array}$ & $\begin{array}{l}\text { 2nd generation, } \\
\text { preparing the } \\
\text { transition to the } \\
\text { 3rd generation }\end{array}$ & $\begin{array}{l}\text { The founder died and had chosen his } \\
\text { oldest son to be his successor. The latter } \\
\text { has been managing the firm until now } \\
\text { but is preparing his son to take it over. } \\
\text { The firm is then preparing for the } 3 \text { rd } \\
\text { generation. }\end{array}$ \\
\hline 6 & $\begin{array}{l}12 \\
\text { years } \\
\text { since } \\
2007\end{array}$ & Dairy product & Second generation & $\begin{array}{l}\text { The founder left the company in the } \\
\text { hands of his } 2 \text { sons and his daughter who } \\
\text { is in charge of the administrative } \\
\text { department. }\end{array}$ \\
\hline 7 & $\begin{array}{l}23 \\
\text { years } \\
\text { since } \\
1996\end{array}$ & $\begin{array}{l}\text { Canned food and } \\
\text { pasta distribution }\end{array}$ & Second generation & $\begin{array}{l}\text { Two brothers started their own business } \\
\text { after leaving their father's business in the } \\
\text { same activity area. }\end{array}$ \\
\hline 8 & $\begin{array}{l}65 \\
\text { years } \\
\text { since } \\
1954 \\
\end{array}$ & $\begin{array}{l}\text { Underwear } \\
\text { manufacturing }\end{array}$ & Second generation & $\begin{array}{l}\text { The founder is still the president, the son } \\
\text { and daughter collaborate with him in } \\
\text { management. }\end{array}$ \\
\hline 9 & $\begin{array}{l}26 \\
\text { years } \\
\text { since } \\
1993 \\
\end{array}$ & Travel Agency & Second generation & $\begin{array}{l}\text { The founder is still there, the son } \\
\text { manages the firm with him, other } \\
\text { members are not active. }\end{array}$ \\
\hline 10 & $\begin{array}{l}15 \\
\text { years } \\
\text { since } \\
2014\end{array}$ & $\begin{array}{l}\text { agricultural } \\
\text { operation }\end{array}$ & Second generation & Two sons, the founder is still working \\
\hline
\end{tabular}


We present below the main surveyed questions of our interviews:

- Do you have any written family governance mechanisms?

- Do you have rules (formal or informal) that regulate all the actions of family members?

- How important are these rules to the relationship between family members?

- If the family has several members, do you find it necessary to set up a family council?

- What is the role of this family council in strengthening family harmony?

- Do you have formal or informal meetings? How important are these meetings?

- Do you find that there's a negative effect on not having rules on the relationships among family members?

- For you what is the main mechanisms (written or not) that you are applying and find it relevant to structure the actions of family members?

\section{Results and Discussions}

In a series of semi-structured interviews and the Focus Group, we were able to explore the Moroccan context and identify a set of results specific to the second generation of Moroccan family businesses. First, we focused on the main governance mechanisms adopted by Moroccan managers. According to them, it is necessary to regulate the actions of family members within the company but not by adopting formal mechanisms. These mechanisms are so hard and difficult to apply, in their opinion. It is not a question of setting up a multitude of governance mechanisms. The unanimity of the responses showed that the main mechanisms to be respected are in particular: to share tasks between family members, to have a common and shared family vision, and finally to respect family meetings, whether formal or informal. These rules are known by all family members and are not necessarily written in a family protocol. Besides, apart from the questions we asked about governance mechanisms, CEOs assert that studying governance in the Moroccan context must shed light on other factors related to the cultural aspect like collectivism, individualism and intergenerational authority.: "It is very important to integrate the cultural variable especially when we protect each other", "we also have to consider the cultural values of the family related to family solidarity". In addition to that, From the interviews, the managers showed that there are conflicts in their family business, between family members. The sources of conflict include a divergence of interest between family members, the ownership of management by several members, and the role conflict that family members may have between their personal and professional lives. Finally, CEOs added that these governance mechanisms, even if they are informal, allow managing conflicts between family members within the company. Considering the above, the main result of our study can be illustrated as shown in (Figure1).

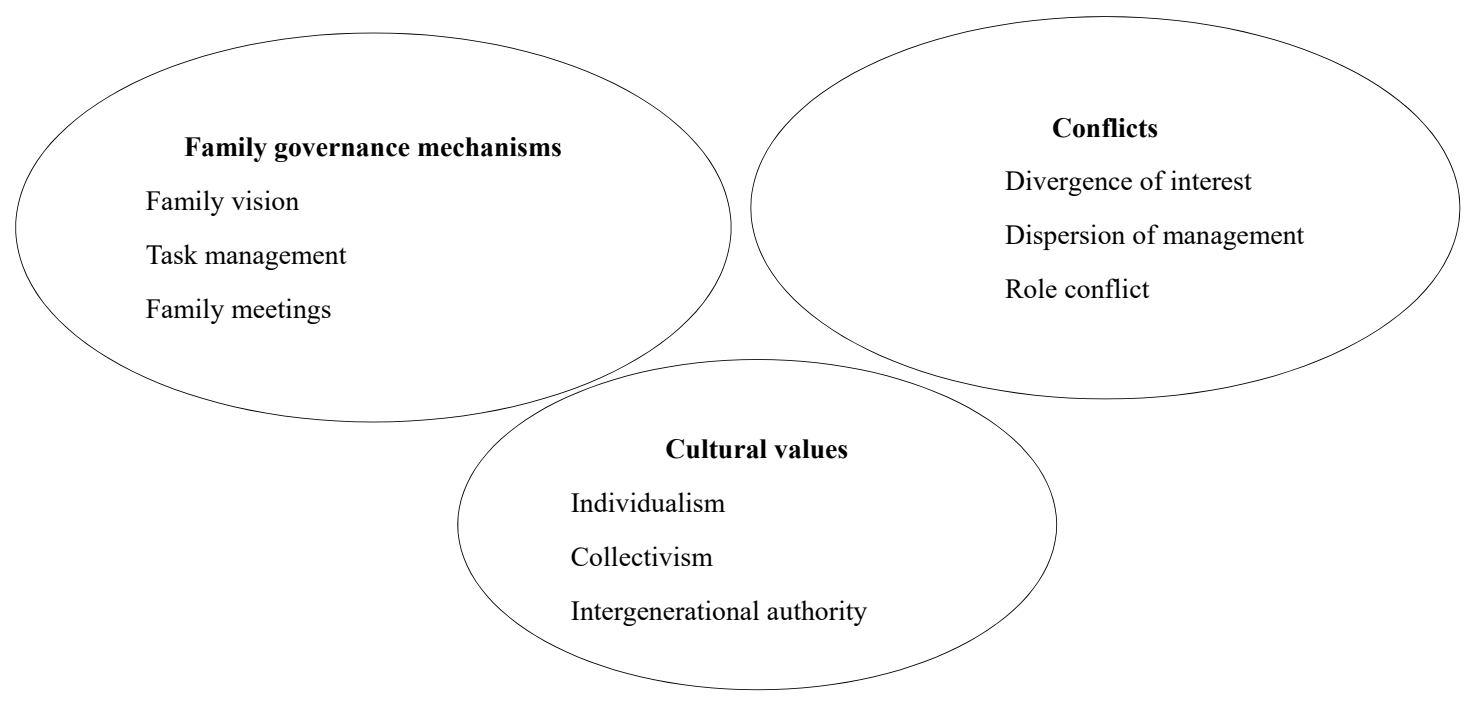

Figure 1. Main results of the exploratory study

We have identified a set of governance mechanisms from literature. The research work developed governance within family businesses, considering them as companies with different characteristics and different management models compared to non-family businesses. Several authors (Davis, 2006; Gersick \& Feliu, 2014) have shown 
the role of governance mechanisms in family firms. They make it possible to regulate the actions of family members while taking into consideration their expectations, visions, values, and goals. These governance mechanisms can be formal or informal, although most research (e.g. Suess, 2014; Shapiro \& al, 2005) has shown the importance of formal governance mechanisms including the family constitution, family board, and family meetings.

Other authors (Chrisman et al., 2017) have shown that these governance mechanisms can be both formal and informal, and are represented by the social values of the stakeholders. Concerning Moroccan Family businesses, none of them have a formal governance structure. In the opinion of Moroccan managers, it is by formalizing and writing official rules that conflicts can overwhelm the firm. This is why we put aside the traditional governance mechanisms stated by the literature and put forward some governance devices adopted by family businesses in the Moroccan context. According to Moroccan managers, traditional mechanisms are hard to apply, they do not prefer to follow a rigid regime but to sensitize family members on some few actions to adopt. During interviews, we identified some of the family governance mechanisms applied by Moroccan CEOs.

\subsection{Task Management}

Moroccan leaders encourage a division of labor with an interest in maintaining interdependence and collaboration. As they see it, it is necessary to divide tasks among family members to avoid conflict between them"...but the best way to prevent or manage conflicts is to share tasks while working in collaboration ...", Also, each one must respect his position without interfering in the work of the other and of course, the alignment of all tasks will be done through communication "As I said earlier the important thing is that each one respects his task and his position, I must not interfere in my brother work and vice versa ....". However, as long as the family members get along via a strong communication link, tasks will be aligned even if they proceed to a division of labor "there must be a division of labor between the family members, the family members must agree on who should take strategic decisions and of course communication is necessary at all times". In other words, the division of tasks helps the family members to be independent and work in collaboration at the same time, but according to them, there's no need to describe the work of each individual in written employee manuals. However, many authors (eg., Kiggundu (1981); Hertel et al. (2007); Kont et al. (2013) have emphasized the idea of maintaining interdependence at work. Thus, Task interdependence is defined as an interaction of tasks in a way to creates coordination (Puranam \& al., 2009: 315). Task interdependence aims to work closely together by ensuring that each individual has his or her own work but shares the necessary resources and knowledge to accomplish these tasks (Bailey et al., 2010).

\subsection{Family Meetings}

In the Moroccan context, all families carry out informal meetings at home over dinner. In their opinion, formal meetings are useless when members live together and can discuss business at any time. "Family meetings are often informal too, over a meal or while watching a football match...» Another says, "Meetings are informally carried out, without having to send an invitation by email, sometimes at home or the office over a coffee. Sometimes, our older brother sends us a Whats App message to invite us to meet at his house to discuss the such-and-such subject. But nothing is formal." Family meetings are an important governance mechanism, whether formal or informal, the most important thing is to be able to discuss with the other family members and to have a clear communication "The best thing is to combine both of them, through communication. A crucial element of family harmony is communication, because when someone is informed he becomes engaged, which does not happen very often. It is necessary to sensitize leaders about communicating information, which can mitigate conflict between family members". In this regard, family meetings are the most common form of family governance in the literature (Neubauer \& Lank 1998, Martin, 2001). The family assembly consists of reuniting the family at least once a year to discuss and provide all the information about the firm. Moreover, it ensures fluent communication, the sense of sharing, trust, and, above all, family harmony (Davis, 2007). It also plays an important role in the transition of the firm to future generations. For this purpose, family members can proceed to the composition of a family board, taking into account all the related matters.

\subsection{Family vision}

Moroccan leaders prefer to share the family vision, to sensitize the members on the spirit of the common vision but do not prefer in any case to formalize it or to get it in writing. "This is not formal, it is not written but it is rather known by all, the values and the vision are known by all the family members, the important thing is not to formalize the governance mechanisms, the important thing is to respect them "; another leader adds "I prefer to raise awareness about values rather than formalize them"; "The values and the vision are known but we do not have a written document". They consider it a major governance mechanism because, according to them, having a 
common vision can lead them to the same target. To have a vision in a family business is to share the goals as well as the path to follow and to build together. For example, family meetings facilitate the sharing of this common vision (Habbershon \& Astrachan, 1997). Indeed, the participation of family members contributes to having a common and shared vision among them (Nahapiet \& Ghoshal, 1998). However, while the family vision must be expressed in a written document signed by all family members within the framework of a family protocol (Berent-Braun \& Uhlaner, 2012), interviews and Focus groups show us that Moroccan CEOs are reluctant to formalize or write family vision in any document. They just prefer to keep it commonly known.

\subsection{Conflicts}

The interviews also allowed us to identify conflicts that emerge between family members. For the leaders, these conflicts are destructive and require an action plan to strengthen family harmony between them. however, the main sources of conflict concern the divergence of interests and the difference in points of view they may have: "Yes, I completely agree, over the interests of the generations become more and more divergent, the transmission of the company becomes more and more complicated, and this is where a structure must be put in place to regulate the actions of the members". Having several people managing the company leads to taking strategic decisions that are harmful to the continuity of the family business in the long term "The family members must agree on a single person who can take strategic decisions ... for example, I see the short term, another who sees the long term, in this case, a decision must be taken, in my opinion, only one person must make the decision that will have the aspect of governance and the others must have the task of monitoring costs, optimization, etc. ...".

This analysis allowed us to identify another source of conflict relating to the concentration of management. And finally, the managers expressed themselves about the confusion they may have about working with family members, sometimes it is difficult to reconcile life at home and life in the company, this confusion of roles is a real source of conflict according to them "Yes, the role conflict exists, It's normal to have role confusion because sometimes we can't judge your performance, there are members who are not competent enough, but no one can show that, if family members are not competent enough to make decisions, there will always be problems. Basically, you have to learn to balance things out and stay professional" These interviews played an important role in exploring governance mechanisms in the Moroccan context that seem to be a crucial element in mitigating conflict.

\subsection{Cultural Values}

As mentioned earlier, we have stated that there are no general rules for setting up a governance system. This being said, in a family business we find the culture of the company and the culture of the family. The cultural context can play an important role in setting up a governance system, for example in the Moroccan context they prefer to keep things implicit and not in writing. Moreover, when we identified conflicts we noticed that they cannot reach a degree of intensity because of the obedience that must exist between children and parents: "There is a conflict of decision making, a generational conflict, despite that we always lean towards the opinion of the first generation", another leader adds: "Sometimes it is part of our culture, we must obey no matter the situation or circumstances, it is good to respect this value and obey". Moreover, the leaders of family businesses share cultural values such as individualism and or collectivism which measures the degree of integration of family members in the family " $a$ family that has grown up in the values of nobleness and the spirit of moral values, all these are factors of family harmony, the most important values are values that go beyond money, the ability to protect oneself no matter what the circumstances", "Self-interest must not be the priority otherwise we will not be able to talk about family harmony".

\section{Conclusion and Future Research}

An effective governance structure requires setting aside the emotional concerns of a family business. It then involves clarifying the strategy, the management, the interface between the family and the company, and, above all, considering the expectations of stakeholders, including family members not involved in management. These can be as destructive as a pressing economic downturn for the firm's future. Their commitment to the firm's future will depend on their ability to make the firm sustainable. The governance of the family business then becomes, to a large extent, a management of family processes that must be framed by the implementation of appropriate governance mechanisms.

There are no universal rules for setting up a governance structure in family businesses from different backgrounds. Hence, it is essential to consider the values, cultures, and intentions of each manager. Our study revealed that the Moroccan context is characterized by governance mechanisms that cannot be evaluated or concretized. Family firms prefer to regulate informally the actions of family members. From their perspective, the most important thing is to adhere to family values, share and preserve them. The conclusive results showed 
also that researchers have to consider the cultural factors in studying the governance of family businesses. Some cultural values can influence or have an impact on the establishment of an effective governance structure.

Governance mechanisms can have a positive impact on the various risks that the firm faces, such as family conflicts. Researchers on family businesses are aware of the negative impact of conflicts on the sustainability and continuity of the family business and also according to interviewees, conflicts among family members are unavoidable. Therefore, we propose a future research agenda on the effects of governance mechanisms on conflict mitigation between family members in the Moroccan context. In another paper, we study governance mechanisms effects on conflict management in the Moroccan context using a quantitative approach.

\section{References}

Allioui, A., \& Habba, B. (2019). Les effets des objectifs non financiers sur l'évaluation des entreprises familiales marocaines: une approche exploratoire. Moroccan Journal of Entrepreneurship, Innovation and Management, $4(1), \quad 29-40, \quad$ Retrieved https://revues.imist.ma/index.php?journal=RMEIM\&page=article\&op=view\&path\%5B $\% 5 \mathrm{D}=16002$

Allouche, J., \& Amann, B. (1998). La confiance: une explication des performances des entreprises familiales. Economies et sociétés, 32, 129-154.

Anderson, R. C., Mansi, S. A., \& Reeb, D. M. (2003). Founding family ownership and the agency cost of debt. Journal of Financial Economics, 68(2), 263-285. https://doi.org/10.1016/S0304-405X(03)00067-9

Arteaga, R., \& Menéndez-Requejo, S. (2017). Family constitution and business performance: Moderating Factors. Family business Review, 30(4), 320-338 https://doi.org/10.1177/0894486517732438

Astrachan, J. H. (2010). Strategy in family business: Toward a multidimensional research agenda. Journal of Family Business Strategy, 1(1), 6-14. https://doi.org/10.1016/j.jfbs.2010.02.001

Astrachan, J. H., \& Shanker, M. C. (2003). Family businesses' contribution to the US economy: A closer look. Family business review, 16(3), 211-219. https://doi.org/10.1177/08944865030160030601

Bailey, D. E., Leonardi, P. M., \& Chong, J. (2010). Minding the gaps: Understanding technology interdependence and coordination in knowledge work. Organization Science, 21(3), 713-730. https://doi.org/10.1287/orsc.1090.0473

Bardin, L. (2013). L'analyse de contenu. Paris cedex 14. France: Presses Universitaires de France. https://doi.org/10.3917/puf.bard.2013.01.

Berent-Braun, M. M., \& Uhlaner, L. M. (2012). Family governance practices and teambuilding: Paradox of the enterprising family. Small Business Economics, 38(1), 103-119. https://doi.org/10.1007/s11187-010-9269-4

Caputo, A., Marzi, G., Pellegrini, M. M., \& Rialti, R. (2018). Conflict management in family businesses: A bibliometric analysis and systematic literature review. International Journal of Conflict Management, 29(4), 519-542. https://doi.org/10.1108/IJCMA-02-2018-0027

Chrisman, J. J. (2019). Stewardship Theory: Realism, Relevance, and Family Firm Governance. https://doi.org/10.1177/1042258719838472

Chrisman, J. J., \& Holt, D. T. (2016). Beyond socioemotional wealth: taking another step toward a theory of the family firm. Management Research: Journal of the Iberoamerican Academy of Management, 14(3), 279-287. https://doi.org/10.1108/MRJIAM-06-2016-0670

Chrisman, J. J., Chua, J. H., \& Litz, R. (2003). A unified systems perspective of family firm performance: An extension and integration. Journal of Business Venturing, 18(4), 467-472. https://doi.org/10.1016/S0883-9026(03)00055-7

Chrisman, J. J., Chua, J. H., Le Breton-Miller, I., Miller, D., \& Steier, L. P. (2018). Governance mechanisms and family firms. https://doi.org/10.1177/1042258717748650

Chrisman, J. J., Chua, J. H., Pearson, A. W., \& Barnett, T. (2012). Family involvement, family influence, and family-centered non-economic goals in small firms. Entrepreneurship theory and practice, 36(2), 267-293. https://doi.org/10.1111/j.1540-6520.2010.00407.x

Chrisman, J. J., Devaraj, S., \& Patel, P. C. (2017). The impact of incentive compensation on labor productivity in family and nonfamily firms. Family Business Review, 30(2), 119-136. https://doi.org/10.1177/0894486517690052

Chrisman, J. J., Sharma, P., Steier, L. P., \& Chua, J. H. (2013). The influence of family goals, governance, and 
resources on firm outcomes. https://doi.org/10.1111/etap.12064

Chua, J. H., Chrisman, J. J., \& Sharma, P. (1999). Defining the family business by behavior. Entrepreneurship theory and practice, 23(4), 19-39. https://doi.org/10.1177/104225879902300402

Combs, J. G., Penney, C. R., Crook, T. R., \& Short, J. C. (2010). The impact of family representation on CEO

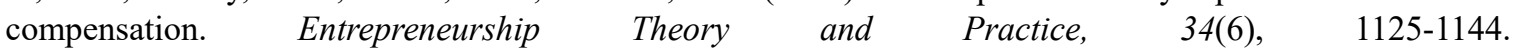
https://doi.org/10.1111/j.1540-6520.2010.00417.x

Daily, C. M., Dalton, D. R., \& Rajagopalan, N. (2003). Governance through ownership: Centuries of practice, decades of research. Academy of Management Journal, 46(2), 151-158. https://doi.org/10.5465/30040611

Davis, J. A. (2006). Governance of the Family Business Owners. https://doi.org/10.2307/30040611

Davis, J. H., Allen, M. R., \& Hayes, H. D. (2010). Is blood thicker than water? A study of stewardship perceptions in family business. Entrepreneurship Theory and Practice, 34(6), 1093-1116. https://doi.org/10.1111/j.1540-6520.2010.00415.x

Davis, J. H., Schoorman, F. D., \& Donaldson, L. (1997). Toward a stewardship theory of management. Academy of Management review, 22(1), 20-47. https://doi.org/10.2307/259223

Dawson, A., \& Parada, M. J. (2019). Corporate Governance in Family Businesses Across Generations: Exploring Intergenerational Issues. In The Palgrave handbook of heterogeneity among family firms (pp. 115-139). Palgrave Macmillan, Cham. https://doi.org/10.1007/978-3-319-77676-7_6

Dyer, W. G. Jr. (1986). Cultural Change in Family Firms: Anticipating and Managing Business and Family Transitions. Jossey-Bass, San Francisco, CA.

Eddleston, K. A., \& Kellermanns, F. W. (2007). Destructive and productive family relationships: A stewardship theory perspective. Journal of Business Venturing, 22(4), 545-565. https://doi.org/10.1177/1042258717748650

Fahed-Sreih, J. (2009). An exploratory study on a new corporate governance mechanism. Management Research News. https://doi.org/10.1108/01409170910922023

Fama, E. F., \& Jensen, M. C. (1983). Agency problems and residual claims. The journal of law and Economics, 26(2), 327-349. http://dx.doi.org/10.2139/ssrn.94032

Feliu, N., \& Botero, I. C. (2016). Philanthropy in family enterprises: A review of literature. Family Business Review, 29(1), 121-141. https://doi.org/10.1177/0894486515610962

Friedman, S. D. (1991). Sibling relationships and intergenerational succession in family firms. Family Business Review, 4(1), 3-20. https://doi.org/10.1111/j.1741-6248.1991.00003.x

Gallo, M. A., \& Kenyon-Rouvinez, D. (2005). The importance of family and business governance. In Family Business (pp. 45-57). Palgrave Macmillan, London. DOI: 10.1057/9780230287730_4

Ge, J., Carney, M., \& Kellermanns, F. (2019). Who fills institutional voids? Entrepreneurs' utilization of political and family ties in emerging markets. Entrepreneurship Theory and Practice, 43(6), 1124-1147. https://doi.org/10.1177/1042258718773175

Gersick, K. E., \& Feliu, N. (2014). Governing the family enterprise: Practices, performance, and research. The SAGE handbook of family business, 196-225. http://dx.doi.org/10.4135/9781446247556.n11

Gersick, K. E., Gersick, K. E., Davis, J. A., Hampton, M. M., \& Lansberg, I. (1997). Generation to generation: Life cycles of the family business. Harvard Business Press.

Gomez-Mejia, L. R., Cruz, C., Berrone, P., \& De Castro, J. (2011). The bind that ties: Socioemotional wealth preservation in family firms. Academy of Management Annals, 5(1), 653-707. https://doi.org/10.1080/19416520.2011.593320

Gómez-Mejía, L. R., Haynes, K. T., Núñez-Nickel, M., Jacobson, K. J., \& Moyano-Fuentes, J. (2007). Socioemotional wealth and business risks in family-controlled firms: Evidence from Spanish olive oil mills. Administrative science quarterly, 52(1), 106-137. https://doi.org/10.2189/asqu.52.1.106

Großmann, S., \& Schlippe, A. V. (2015). Family businesses: fertile environments for conflict. Journal of Family Business Management, 5(2), 294-314. https://doi.org/10.1108/JFBM-11-2014-0038

Habba, B., \& ElAzizi, T. B. (2018). Vers une approche spécifique de gouvernance de l'entreprise familiale. Revue africaine de management, 3(1). Retrieved from https://revues.imist.ma/index.php?journal=RAM\&page=article\&op=view\&path\%5B\%5D=10909 
Habbershon, T. G., \& Astrachan, J. H. (1997). Research note: Perceptions are reality: How family meetings lead to collective action. Family Business Review, 10(1), 37-52. https://doi.org/10.1111/j.1741-6248.1997.00037.x

Habbershon, T. G., \& Williams, M. L. (1999). A resource-based framework for assessing the strategic advantages of family firms. Family business review, 12(1), 1-25. https://doi.org/10.1111/j.1741-6248.1999.00001.x

Hall, A., Melin, L., \& Nordqvist, M. (2001). Entrepreneurship as radical change in the family business: exploring the role of cultural patterns. Family Business Review, 14(3), 193-208. https://doi.org/10.1111/j.1741-6248.2001.00193.x

Handler, W. C. (1994). Succession in family business: A review of the research. Family business review, 7(2), 133-157. https://doi.org/10.1111/j.1741-6248.1994.00133.x

Hertel, G., Konradt, U., \& Orlikowski, B. (2004). Managing distance by interdependence: Goal setting, task interdependence, and team-based rewards in virtual teams. European Journal of work and organizational psychology, 13(1), 1-28. https://doi.org/10.1080/13594320344000228

Hirigoyen, G. (2009). Concilier finance et management dans les entreprises familiales. Revue française de gestion, (8), 393-411.

Hirigoyen, G. (2014). Valeur et évaluation des entreprises familiales. Revue française de gestion, 242(5), 119-134.

International Family Enterprise Research Academy (IFERA). (2015). Family Businesses Dominate: International Family Enterprise Research Academy (IFERA). Family Business Review.

Jaffe, D. T., \& Lane, S. H. (2004). Sustaining a family dynasty: Key issues facing complex multigenerational business-and investment-owning families. Family Business Review, 17(1), 81-98. https://doi.org/10.1111/j.1741-6248.2004.00006.x

Jehn, K. A. (1995). A multimethod examination of the benefits and detriments of intragroup conflict. Administrative science quarterly, 256-282. https://doi.org/10.2307/2393638

Jensen, M. C., \& Meckling, W. H. (1976). Theory of the firm: Managerial behavior, agency costs and ownership structure. Journal of financial economics, 3(4), 305-360. https://doi.org/10.1016/0304-405X(76)90026-X

Jiang, D. S., \& Munyon, T. P. (2016). More than a feeling: The promise of experimental approaches for building affective and cognitive microfoundations of family firm behavior. In The Routledge companion to family business (pp. 415-430). Routledge. https://doi.org/10.4324/9781315688053.ch19

Julia, S. (2014). Family governance - Literature review and the development of a conceptual model. Journal of Family Business Strategy, 5(2), 138-155. https://doi.org/10.1177/0894486517736959

Kiggundu, M. N. (1981). Task interdependence and the theory of job design. Academy of management Review, 6(3), 499-508. https://doi.org/10.2307/257385

Klein, P., Shapiro, D., \& Young, J. (2005). Corporate governance, family ownership and firm value: the Canadian evidence. Corporate Governance: An International Review, 13(6), 769-784. https://doi.org/10.1111/j.1467-8683.2005.00469.x

Koiranen, M. (2002). Over 100 years of age but still entrepreneurially active in business: Exploring the values and family characteristics of old Finnish family firms. Family Business Review, 15(3), 175-187. https://doi.org/10.1111/j.1741-6248.2002.00175.x

Kont, K. R., \& Jantson, S. (2013). Division of labor and coordination, intra-organizational career and salary fairness. Library management. https://doi.org/10.1108/LM-10-2012-0069

Lee, T. (2019). Management ties and firm performance: Influence of family governance. Journal of Family Business Strategy, 10(2), 105-118. https://doi.org/10.1016/j.jfbs.2018.12.003

Madison, G., Mosing, M. A., Verweij, K. J., Pedersen, N. L., \& Ullén, F. (2016). Common genetic influences on intelligence and auditory simple reaction time in a large Swedish sample. Intelligence, 59, 157-162. https://doi.org/10.1016/j.intell.2016.10.001

Madison, K., Kellermanns, F. W., \& Munyon, T. P. (2017). Coexisting agency and stewardship governance in family firms: An empirical investigation of individual-level and firm-level effects. Family Business Review, 30(4), 347-368. https://doi.org/10.1177/0894486517727422

Martin, H. F. (2001). Is family governance an oxymoron? Family Business Review, 14(2), 91-96. 
https://doi.org/10.1111/j.1741-6248.2001.00091.x

Mckee, D., Madden, T. M., Kellermanns, F. W., \& Eddleston, K. A. (2014). Conflicts in family firms: The good and the bad. Sage handbook of family business, 514-528. http://dx.doi.org/10.4135/9781446247556.n26

Minichilli, A., Nordqvist, M., Corbetta, G., \& Amore, M. D. (2014). CEO succession mechanisms, organizational context, and performance: A socio-emotional wealth perspective on family-controlled firms. Journal of Management Studies, 51(7), 1153-1179. DOI: 10.1111/joms. 12095

Mustakallio, M., Autio, E., \& Zahra, S. A. (2002). Relational and contractual governance in family firms: Effects on strategic decision making. Family business review, 15(3), 205-222. https://doi.org/10.1111/j.1741-6248.2002.00205.x

Nahapiet, J., \& Ghoshal, S. (1998). Social capital, intellectual capital, and the organizational advantage. Academy of management review, 23(2), 242-266. https://doi.org/10.2307/259373

Neubauer, F., \& Lank, A. (1998). The Family Business: Its Governance for Sustainability. Macmillan Press Ltd., Houndmills.

Olson, P. D., Zuiker, V. S., Danes, S. M., Stafford, K., Heck, R. K. Z., \& Duncan, K. A. (2003). The impact of the family and the business on family business sustainability. Journal of Business Venturing, 18(5), 639-666. https://doi.org/10.1016/S0883-9026(03)00014-4

Parada, M. J., \& Viladás, H. (2010). Narratives: a powerful device for values transmission in family businesses. Journal of Organizational Change Management, $23(2), \quad$ 166-172. https://doi.org/10.1108/09534811011031346

Pearson, A. W., \& Marler, L. E. (2010). A leadership perspective of reciprocal stewardship in family firms. Entrepreneurship Theory and Practice, 34(6), 1117-1124. https://doi.org/10.1111/j.1540-6520.2010.00416.x

Pekdemir, I., Koçoglu, M., \& Gürkan, G. Ç. (2013). The effects of harmony of family, distributive justice, and role ambiguity on family member impediment: The mediating role of relationship conflict as an example of developing country Turkey. Asian Social Science, 9(9), 131. https://doi.org/10.5539/ass.v9n9p131

Pieper, T. M., \& Astrachan, J. H. (2008). Mechanisms to assure family business cohesion: Guidelines for family business leaders and their families. Kennesaw, GA: Cox Family Enterprise Center. $\mathrm{http}$ ///works.bepress.com/torsten_pieper/21/

Pollak, R. A. (1985). A transaction cost approach to families and households. Journal of economic Literature, 23(2), 581-608. https://doi.org/10.1111/j.1728-4457.2014.00674.x

Puranam, P., Singh, H., \& Chaudhuri, S. (2009). Integrating acquired capabilities: When structural integration is (un) necessary. Organization Science, 20(2), 313-328. https://doi.org/10.1287/orsc.1090.0422

Romano, C. A. (2000). Capital structure decision making: A model for family business. Journal of business Venturing, 16, 285-310. https://doi.org/10.1016/S0883-9026(99)00053-1

Schulze, W. S., Lubatkin, M. H., \& Dino, R. N. (2003). Toward a theory of agency and altruism in family firms. Journal of business venturing, 18(4), 473-490. https://doi.org/10.1016/S0883-9026(03)00054-5

Schulze, W. S., Lubatkin, M. H., Dino, R. N., \& Buchholtz, A. K. (2001). Agency relationships in family firms: Theory and evidence. Organization science, 12(2), 99-116. https://doi.org/10.1287/orsc.12.2.99.10114

Siebels, J. F., \& ZuKnyphausen-Aufseß, D. (2012). A review of theory in family business research: The implications for corporate governance. International Journal of Management Reviews, 14(3), 280-304. https://doi.org/10.1111/j.1468-2370.2011.00317.x

Sirmon, D. G., \& Hitt, M. A. (2003). Managing resources: Linking unique resources, management, and wealth creation in family firms. Entrepreneurship theory and practice, 27(4), 339-358. https://doi.org/10.1111/1540-8520.t01-1-00013

Steier, L. P., Chrisman, J. J., \& Chua, J. H. (2015). Governance challenges in family businesses and business families. https://doi.org/10.1111/etap.12180

Suáre, K. C., \& Santana-Martín, D. J. (2004). Governance in Spanish family business. International Journal of Entrepreneurial Behavior \& Research, 10(1/2), 141-163. https://doi.org/10.1108/13552550410521425

Suess, J. (2014). Family governance-Literature review and the development of a conceptual model. Journal of Family Business Strategy, 5(2), 138-155. https://doi.org/10.1016/j.jfbs.2014.02.001 
Tàpies, J., \& Fernández Moya, M. (2012). Values and longevity in family business: Evidence from a cross-cultural analysis. Journal of Family Business Management, 2(2), 130-146. https://doi.org/10.1108/20436231211261871

Thietart, R. A. (2014). Méthodes de recherche en management. Paris, Dunod. Retrieved from https:/www.dphu.org/uploads/attachements/books/books_222_0.pdf

Tower, C. B., Gudmundson, D., Schierstedt, S., \& Hartman, E. A. (2007). Do family meetings really matter? Their relationship to planning and performance outcomes in small family businesses. Journal of Small Business Strategy, 18(1), 85-94. https://161.45.205.92/index.php/jsbs/article /view/79

Vallejo, M. C. (2009). The effects of commitment of non-family employees of family firms from the perspective of stewardship theory. Journal of business ethics, 87(3), 379-390. https://doi.org/10.1007/s10551-008-9926-6

Ward, J. L. (1997). Growing the Family Business: Special Challenges and Best Practices. Family Business Review, 10(4). https://doi.org/10.1111/j.1741-6248.1997.00323.x

Whiteside, M. F., \& Brown, F. H. (1991). Drawbacks of a dual systems approach to family firms: Can we expand our thinking? Family business review, 4(4), 383-395. https://doi.org/10.1111/j.1741-6248.1991.00383.x

Williams Jr, R. I., Pieper, T. M., Kellermanns, F. W., \&Astrachan, J. H. (2018). Family firm goals and their effects on strategy, family and organization behavior: A review and research agenda. International Journal of Management Reviews, 20, S63-S82. DOI: 10.1111/ijmr.12167

Zellweger, T. M., Chrisman, J. J., Chua, J. H., \& Steier, L. P. (2019). Social structures, social relationships, and family firms. https://doi.org/10.1177/1042258718792290

Zellweger, T. M., Eddleston, K. A., \& Kellermanns, F. W. (2010). Exploring the concept of familiness: Introducing family firm identity. Journal of Family Business Strategy, 1(1), 54-63. https://doi.org/10.1016/j.jfbs.2009.12.003

\section{Note}

Note 1. FGM: Family governance mechanisms.

\section{Copyrights}

Copyright for this article is retained by the author(s), with first publication rights granted to the journal.

This is an open-access article distributed under the terms and conditions of the Creative Commons Attribution license (http://creativecommons.org/licenses/by/4.0/). 